\title{
Pálfi, Loránd-Levente 2010. Leksikon over ordbøger og leksika. Under medvirken af John- ny Finnssøn Lindholm. København: Frydenlund. 432 pages. ISBN 978-87-7887-838-0
}

\section{Introduktion}

Loránd-Levente Pálfi har - under medvirken af Johnny Finnssøn Lindholm - i ovennævnte værk foretaget en kortlægning af samtlige danske leksikografiske opslagsværker fra nyere og nyeste tid. Der er således tale om et metaleksikon og dermed en nøgle til identifikation af ordbøger og leksika med dansk som genstandssprog. Pálfi udnævner værket til at være det første af sin slags på dansk (p. 10), en vurdering, som jeg erklærer mig enig $\mathrm{i}$ - især i lyset af de forbehold og garderinger, som Pálfi anfører i den sammenhæng. I det nedenstående vil jeg give en beskrivelse og bedømmelse af de væsentligste dele og aspekter af bogen og i henhold til Bergenholtz/Tarps (1990: 256) tabel over anmeldelseskategorier bl.a. komme ind på brugergruppen, ordbogsfunktionerne, omteksten og lemmaselektionen samt foretage en subjektiv stikprøve af lemmata.

\section{Formål}

"Bogen er tænkt som et praktisk værktøj til informationssøgning." (bagsiden), eller, som det hedder mere detaljeret, bogens sigte er

\footnotetext{
at give en nutidsorienteret og i forhold til konkret informationssøgning praksisorienteret oversigt over fagordbøger, sprogordbøger og specialordbøger. Brugeren skal her kunne finde oplysning om, hvad der faktisk findes på dansk i nyere og nyeste tid, og hvor meget der findes inden for alle mulige fagområder, specialområder (som ikke hører ind under et bestemt fag) og om alskens forskellige sprog (dvs. de forskellige sprogretninger til og fra dansk). (p. 11).
}

Det er kendetegnende for de ca. 50 siders omtekst, at Pálfi er særdeles grundig, udførlig og detaljeret og derved af og til kommer til at sige det samme flere gange. Det ser jeg dog ikke nødvendigvis altid som nogen ulempe, idet mange af hans vigtige pointer bestemt fortjener gentagelse i forskellig form. Målsætningen gives da også i følgende formulering:

\begin{abstract}
Der findes ordbøger og leksika om næsten alt mellem himmel og jord. Også på et forholdsvis lille sprog som dansk. Men de fleste mennesker (inkl. fagfolk og studerende) er ikke klar over det. Det er min ambition at give syn for sagn: Her skal én gang for alle vises et så bredt og så omfattende udsnit af dansk leksikografi, som det overhovedet lader sig gøre i en bog af et sådant omfang, med et sådant ambitionsniveau og udarbejdet med de resurser som denne. (p. 17).
\end{abstract}

Ambitionen må siges at være blevet indfriet til fulde.

\section{Målgruppe}

Målgruppen angives ganske detaljeret i tre lag, nemlig den primære målgruppe, som er "den studerende ungdom" (p. 12), den sekundære målgruppe, som er "det praktiserende lag af fagfolk" (p. 12), og den tertiære målgruppe, som er den nærmest obligate "alle, der interesserer sig" (p. 12). Pálfi bruger meget klædeligt en god halv side på at revse de ordbogs- og leksikonforfattere og -redaktører, der ved netop at angive målgruppen som "alle, der interesserer sig" for et bestemt fagområde ikke definerer målgruppen (tilstrækkeligt). Han peger dermed på et fænomen, der ikke kun ses inden for leksikografien, men generelt i lærebøger, fagbøger og videnskabelige monografier, nemlig at så at sige alle forord og alle bagsidetekster altid for en sikkerheds skyld henvender sig til den brede gruppe "alle, der interesserer sig" for at eventuelle købere endelig ikke skulle blive skræmt bort af en for snæver målgruppeafgrænsning.

På trods af en meget høj grad af videnskabelig lødighed og forskningsbasering forstår værket sig som en "populærvidenskabelig og ikke en videnskabelig fremstilling." (p. 13). Det lykkes da også meget godt at holde fokus på denne beslutning. Således er - ud over at brugervenligheden er meget høj (jf. nedenfor) - omteksterne doseret, så at den primære målgruppe kan nøjes med de omtekster, 
der er relevante for dem, dvs. grundlæggende (og realistisk) den korte indledende bemærkning (p. 9) og de "Fire gode og vigtige råd!" (p. 50). Her er det i øvrigt betegnende, at den "til tider kontroversielle orddeling" allerede nævnes i den korte indledende bemærkning, sikkert vel vidende, at mange vil tage anstød af den. Den - med en lettere eufemistisk formulering betegnede - "mere fantasifuld[e] omgang med bindestreger" motiveres overbevisende i brugervejledningen (p. 47).

\section{Opbygning (komponenter)}

Bogen består af følgende dele:

"En kort indledende bemærkning" (p. 9) er en slags metakommunikativ vejledning til vejledningen, hvor brugeren får at vide, hvilke af omteksterne der er relevante for en almindelig bruger fra primærmålgruppen og hvilke der henvender sig til "semifagfolk, fagfolk og akademikere" (p. 9). Denne vejledning til omteksterne er meget hensigtsmæssig, idet overskrifterne ikke nødvendigvis er selvforklarende, og da slet ikke for den primære målgruppe.

I forordet (p. 10-19) kommer Pálfi ind på leksikonets status (første af sin slags på dansk, metaleksikon, populærvidenskabelig fremstilling), og han motiverer udgivelsen med den eksponentielle stigning i produktionen af information i den seneste tid. Som udgangspunkt mener jeg ikke, at det er hensigtsmæssigt at forsøge at kvantificere viden ved at måle eller tælle bogbestanden, antal sider eller bytes. Men lige præcis i forbindelse med et sådant leksikon over ordbøger og leksika giver det god mening at illustrere den pointe, at mængden af information er i konstant, tiltagende og overvældende stigning, med angivelser af svimlende tal (p. 11).

I kapitlet "Leksikografi i dag" (p. 19-21) havde jeg forventet et kort rids over disciplinen, men i stedet for er der snarere tale om en typologi af ordbøger og leksika, som i en kommende udgave med fordel enten kunne omdøbes eller integreres i en af de andre omtekster, fx forordet. Indholdet er således yderst relevant, men skuffer lidt på baggrund af kapiteloverskriften.

Det samme gælder for en kort "[t]eoretisk bemærkning" (p. 21-23), som kommenterer leksikografiske "dekalibreringstyper", dvs. en uligevægt i prioritering og tilbørlig hensyntagen til "den leksikografiske trekant (bruger - data - tilgang)" (p. 22). Også dette kapitel er særdeles relevant, men kunne uden videre skrives ind i en samlet omtekst omkring leksikografisk teori.

Det empiriske datagrundlag beskrives i "Afgrænsning af genstandsområdet" (p. 23-29), hvor man bl.a. finder den meget centrale tidsafgrænsning (efter 1990 og til og med første halvår 2009, p. 24f.) og den afgørende definition af de ordbøger, der indgår i datagrundlaget, nemlig danske sprogordbøger og danske fagordbøger som er dokumenter, "som har dansk som genstandssprog", som har hhv. fagligt markeret og ikke fagligt markeret indhold og "som opfylder kriterierne for at kunne kaldes leksikografisk opslagsværk.” (p. 23).

Definitionen på dette begreb skal man så i øvrigt finde andetsteds, nemlig i kapitlet "Selektion og selektionskriterier" (p. 29-34):

\footnotetext{
Ved leksikografisk opslagsvæerk forstås i nærværende sammenhæng et værktøj, som er udarbejdet med det formål at tilvejebringe en bestemt type data og gøre disse tilgængelige på en sådan måde, at en bestemt type brugere, som befinder sig i en bestemt type brugersituation [...], gennem søgning i det pågældende leksikografiske opslagsværk kan hente informationer med henblik på løsning af en bestemt type problem [...]. (p. 31).
}

I kapitlet gives en meget detaljeret og eksplicit beskrivelse af den meget operationelle fremgangsmåde ved identifikationen af de dokumenter, der inddrages i bibliografien. Pálfi har systematisk og konsekvent screenet den nationale biblioteksdatabase www.bibliotek.dk for dokumenter, der enten indeholder én af alle mulige tænkelige former for bogstavsspektre (fx "A til Z", "A-Z", "A til §” m.fl.) eller en genrebetegnelse (fx "billedordbog", "database", "encyklopædi", "leksikon", "minilex", "ordbog", "ordliste" m.fl.) (p. 31).

Brugervejledningen (p. 35-47) starter meget praktisk med en symbolforklaring for de markører, der strukturerer ordbogsartiklerne, nemlig - til markering af omtalen af et konkret værk - et 
meget hensigtsmæssigt træk til at finde de enkelte værker i meget lange artikler som fx dansk (p. 84-91, 14 spalter, 30 værker) eller økonomi (p. 250-255, 10 spalter, 44 værker); || til markering af (tematiske) sektioner i en artikel (ligeledes meget brugervenligt og befordrende for at danne sig et hurtigt overblik); som markering af funktionen "se også" og som markering af funktionen "se" (hvorved nødvendigheden af at skelne mellem de to funktioner ikke er helt indlysende). De efterfølgende meget udførlige beskrivelser af måden at strukturere artiklerne på er en prisværdig dokumentation af, at Pálfi absolut ikke overlader noget til tilfældighederne, men er bevidst og eksplicit omkring sine beslutninger, fx vedr. rækkefølgen, i hvilken de enkelte dokumenter omtales $\mathrm{i}$ artiklerne, at det som udgangspunkt altid er det nyeste værk/den seneste udgave, der omtales, hvem af en stribe af medredaktører nævnes, hvis der er mange o.a. Det må dog betvivles, om brugeren fra den primære målgruppe vil finde så detaljerede udredninger relevante - også selvom Pálfi lægger op til, at hele brugsvejledningen skal læses af brugerne (p. 9).

"Yderligere litteratur, foreninger og forskning" (p. 47-50) indeholder til dels det, man egentlig bl.a. kunne forvente under "Leksikografi i dag" (se ovenfor), fx en kort omtale af andre oversigter og bibliografier over danske eller skandinaviske ordbøger, af leksikografiske tidsskrifter og foreninger.

"Fire gode og vigtige råd" (p. 50) er en komprimeret brugervejledning. Det taler for Pálfis realistiske vurdering af målgruppen, især den primære, at han giver mulighed for at springe den 8 sider lange brugervejledning over (selv om han som sagt lægger op til, at den skal læses for at få fuldt udbytte af bogen).

Opslagsdelen er med sine godt 200 sider naturligvis bogens kerne (p. 51-255). Den er alfabetisk sorteret, tospaltet og med lemmata i fed tryk og rykket ud til venstre, hvilket sammen med de ovennævnte typografiske markører giver en høj grad af overblik og dermed brugervenlighed. Indholdsmæssigt omtales opslagsdelen mere udførligt nedenfor.

Bibliografien (p. 256-426) er det skatkammer af danske ordbøger og leksika, som opslagsdelen er nøglen til. Her findes de komplette bibliografiske oplysninger om de 1.416 dokumenter, som er gennemnummereret og opført i alfabetisk rækkefølge efter forfatter eller redaktør. Bibliografien inkluderer også "Anden litteratur" (p. 404-426), der er opført særskilt og som indeholder sekundærlitteratur: "I den ene del er anført primærlitteraturen, hvilket i denne sammenhæng vil sige de leksikografiske opslagsværker, mens den anden del indeholder sekundærlitteraturen, dvs. litteratur om de omtalte leksikografiske opslagsværker.” (p. 42).

Endelig finder man en kort tekst om forfatterne (p. 427-430) samt et par korte rettelser og tilføjelser (p. 431-432).

\section{Test af opslagsdelen}

Som anmelder viser det sig, at jeg faktisk ikke umiddelbart hører til nogen af de tre prioriterede målgrupper, idet jeg ikke hører til den studerende ungdom (længere), idet jeg heller ikke kan henregnes til det praktiserende lag af fagfolk, og idet jeg egentlig ikke interesserer mig nævneværdigt for leksikografi. Imidlertid kan jeg som forsker i dansk-tysk kontrastiv sprogbrug og interkulturel markeds- og virksomhedskommunikation i høj grad få gavn af værket, ligesom en hvilken som helst forsker - og en hvilken som helst fagmand eller lægperson der vil vide, hvilke værker der findes på et givent område - vil kunne bruge værket for at se, hvad der findes af danske ordbøger og leksika på hans eller hendes område. Jeg har læst opslagsordene igennem og konstateret, at der er både forventelige og højst overraskende fagområder, inden for hvilke der findes danske ordbøger eller leksika. Det kan således ikke undre, at fagområderne botanik, medicin og økonomi og sprogene dansk, tysk og engelsk efterfølges af lange artikler med mange referencer til bibliografidelen. Derimod kan det overraske, at nogen har fundet det umagen værd at forfatte og publicere en ordbog eller et leksikon om kaktusser, dagsommerfugle og omfalofobi og om sprog som espemondo, jiddisch eller norrønt. At Pálfi ikke nævner noget om selektionen af lemmata, inkl. krydshenvisninger (fx fra idræt til sport eller fra dagsommerfugle til insekter), kan man dårligt klandre ham for. Der er nu engang de ordbøger og leksika der er, og de behandler nu engang de sprog og fagområder, som 
de gør, så lemmaselektionen giver sig til en hvis grad selv. I et så næsten ekstremt gennemarbejdet værk kunne det ikke desto mindre have været fint med et par linjer om lemmaselektionen, selv hvis det bare havde været en lakonisk konstatering af, at lemmata er udvalgt på baggrund af de faktiske publikationer samt en intuitiv/snusfornuftig supplering ved oplagte synonymer, hyponymer og hyperonymer. En anden ting, jeg studser en anelse over, er selektionen af naturlige sprog som lemmata. Her kunne Pálfi passende have brugt samme meget rimelige overvejelser, som han har gjort sig omkring rækkefølgen af de enkelte publikationers omtale i en given artikel, nemlig at "[d]et, som kulturelt eller geografisk er tættest på, nævnes først." (p. 37). For selv om beslutningen om at samle fx inupik, sranan og rapanui under et 'opsamlingslemma' kaldet "meget sporadisk dækkede sprog" (p. 170f.) er aldeles fornuftig, så fremgår det ikke af nogen af omteksterne og kan heller ikke umiddelbart rekonstrueres, hvorfor inupik, der tales i det formodentligt ekstremt tyndt befolkede område omkring Beringsstrædet, rapanui med sine 3.400 modersmålstalende og sranan med sine 310.000 modersmålstalende har egne lemmata med henvisninger til ovennævnte samlekategori, når nu der - alt efter kategorisering og definition - skønsvis findes mellem 3.000 og 8.000 sprog i verden (se eksempelvis Glück 2000: 653, Arndt 2003: 221, Munk m.fl. 2008: 8 eller www.ethnologue.com): Hvilket sprog skal så nævnes og hvilket ikke, og på baggrund af hvilke kriterier?

Jeg har ledt efter følgende opslagsord, baseret på forskningsmæssig og privat interesse: chokolade, fodbold, funk, jazz, humor, lingvistik, reklame, sex, snaps, sønderjysk, tysk, tv og øl. Chokolade, fodbold, funk, humor og reklame har ingen lemmata, dvs. der findes ingen danske leksikografiske opslagsværker om disse specifikke fagområder. Dog kan man med lidt kreativ søgeteknik finde frem til overordnede og beslægtede områder som sport (et lemma man også henvises til, hvis man søger under idræt), hvor man finder tre mere generelle opslagsværker og derudover bliver henvist til cykling, golf, ridning og speedway, som igen har deres egne opslagsværker. Man kan således med sindsro gå i krig med at lave et leksikon eller en ordbog om fodbold, idet den grundige og systematiske research turde have sikret, at der ikke er overset noget. At der ikke findes noget om reklame kan undre lidt, men her er det igen et spørgsmål om at finde kvasi-synonymer, idet markedsføring (et lemma man også henvises til, hvis man søger under marketing) er repræsenteret. Og med lidt mere kreativ og hårdnakket søgen kan man (evt. via tv, fjernsyn) finde frem til lemmaet film, medier og kommunikation, hvor der blandt de syv nævnte værker findes Mediehåndbogen og Medie- og Kommunikationsleksikon, begge to værker, som også kommer ind på mange marketing- og reklamerelaterede områder.

Jazz, lingvistik, sex, snaps, sønderjysk, tysk, tv og øl har derimod artikler med referencer til relevante værker. Sønderjysk findes som lemma, men man henvises til samlekategorien 'danske dialekter', hvor der til gengæld grundet den meget overskuelige og brugervenlige typografi kan findes frem til de relevante sønderjyske ordbøger. Med Nordmann-Stabenow 1994 har Pálfi også fundet frem til ordbøger udgivet uden for Danmark, men det angives også som mulighed (p. 23). Jeg savner dog - især i lyset af det anmeldte værks grundighed og bredde - Else Christensens Oespråg å Oebogh o synnejysk (2003) og Herbert Matzens Sønderjyske ord og vendinger på Højeregnens dialekt (2004). For Christensen (2003) kunne fravalget have skyldtes den leksikografifaglige lave kvalitet, men både Lønne (1999) og Mårup (2001) - "to ualmindeligt små online-ordlister af tvivlsom kvalitet" (p. 92) er medtaget. At Matzen (2004) ikke er medtaget kan evt. skyldes, at titlen ikke indeholder nogen af de søgeord, som Pálfi har anvendt ved den systematiske gennemgang af www.bibliotek.dk som fx "glossar", "leksikon", "ordbog", "ordliste" (p. 31). Men begge værker er dog nævnt i Nielsen/Zethsen 2004, som Pálfi henviser til.

\subsection{Omfalofobi}

Som lille kuriosum skal nævnes den meget læseværdige artikel under lemmaet omfalofobi. Omfalofobi er "sygelig angst for sin egen navle" (p. 183). Jeg har ganske vist ikke kunnet verificere selve ordet i en autoriseret kilde, men jf. Hårbøl m.fl. (1999: 672) er "omfalo- (el. omfal-) navle-, 
vedr. navlen" åbenbart ret produktivt, ligesom "-fobi" også er det, så ordet kan i hvert fald konstrueres efter almindelige (fremmed)orddannelsesregler. Opslagsordet illustrerer på glimrende vis Pálfis pointe om, at der findes ordbøger om næsten alt mellem himmel og jord, jf. ovenfor. Og at der ligefrem skulle findes et, som det hedder, "ambitiøst leksikografisk opslagsværk" forfattet af "en af de mest fremtrædende navlekirurger i 1980'ernes Transsylvanien" som er oversat fra transsylvansk ungarsk til dansk, underbygger udsagnet desto mere. Netop dette opslagsord har da også fundet avisanmeldelsernes (som Pálfi dog synes er "generelt inkompetente, intetsigende og ligegyldige.” p. 43) bevågenhed, idet Bjørnkjær (2010) eksplicit nævner dette lemma. Imidlertid har jeg en fornemmelse af, at det er en anden af Pálfis pointer, som han vil fremme med denne artikel om omfalofobi, nemlig "[d]en gyldne bibliografiske regel om, at man skal have haft dokumentet i hænde" (p. 15f.). Ellers er der tale om "fantomdokumenter, dvs. dokumenter, som reelt ikke eksisterer (de eksisterer kun i nogle kataloger, bibliografier eller andre databaser, det være bogtrykte eller online)" (p. 28). Og trods de ganske mange meget konkrete og detaljerede (og kuriøse) oplysninger, som Pálfi angiver om Etnevel-Dnárol Ifláps Leksikon om omfalofobi, omfalopsykitte tilbøjeligheder, omfalomantik, omfalektomi og hesykaster, så ville jeg være ret varsom med at referere til dette værk uden ved selvsyn at have overbevist mig om dets eksistens. Det er i hvert fald påfaldende, at forfatterens navn stavet bagfra udgør Pálfis fulde navn. Så det må derfor også hermed siges at være blevet gendrevet, at leksikografer ikke har humor.

\section{Samlet vurdering}

Alt $i$ alt er der her tale om et leksikon, der er akribisk i sin beskrivelse, argumentation og dokumentation af sit genstandsområde og hvis detaljeringsgrad i omteksterne ikke med nogen som helst form for rimelighed kan forlanges bedre. Det er endvidere et opslagsværk, som jeg vurderer til at være overordentligt anvendeligt, idet brugervenligheden - målt på de tre lagdelte målgrupper - er særdeles høj. Bogens eksistensberettigelse er uomtvistelig, dens brugervenlighed særdeles høj og dens anvendelighed for forskere, der ellers ikke var tænkt som målgruppe, ligeledes meget høj. Så med risiko for at udvande Pálfis så akkurate målgruppebeskrivelser vil jeg tillade mig at anbefale bogen varmt til alle brugere fra gymnasialt niveau og opefter. Man må ønske for den, at den vil opleve mange opdateringer og nye udgaver efterhånden, som den i gennemsnit ugentlige publikation af et nyt opslagsværk med dansk som genstandssprog (jf. p. 14) gør det nødvendigt, for den rammer lige midt ind i hjertet af informationssamfundet, sådan som det lille gruk af Piet Hein på titelbladet så fortræffeligt udtrykker: "At vide, hvor man får besked, er mere værd end det, man ved".

\section{Litteratur}

Arndt, Hans 2003: Sproget. Hverdagens mirakel. Århus: Århus Universitetsforlag.

Bergenholtz, Henning/Tarp, Sven 1994: Manual i fagleksikografi. Udarbejdelse affagordbøger. Problemer og løsningsforslag. Herning: Systime.

Bjørnkjær, Kristen 2010: Leksikon over leksika. I: Information 8.10.2010 [online]. http://www.information.dk/223944 (tilgået 17.1.2011).

Christensen, Else 2003: Oespråg å Oebogh o synnejysk. Ordsprog og ordbog på sønderjysk. Skærbæk.

Glück, Helmut (ed.) 2000: Metzler Lexikon Sprache. Stuttgart/Weimar: Metzler.

Hårbøl, Karl/Schack, Jørgen/Spang-Hanssen, Henning 1999: Dansk Fremmedordbog. 2. udgave. København: Gyldendalske Boghandel, Nordisk Forlag.

Kolstrup, Søren/Agger, Gunhild/Jauert, Per/Schrøder, Kim (red.) 2009: Medie- og Kommunikationsleksikon. Frederiksberg: Samfundslitteratur.

Munk, Linda Svenstrup/Risager, Karen/Wille, Niels Erik 2008: Den sproglige verden. Sprogsociologi, sprogpsykologi, sprogfilosofi. Århus: Systime.

Lønne, Yrsa 1999: Så’en snakke vi i Ballum [online]. http://www.synnejysk.dk (tilgået 17.1.2011).

Matzen, Herbert 2004: Sønderjyske ord og vendinger på Højeregnens dialekt. Højer. 
Mortensen, Frands/Poulsen, Jørgen/Stigel, Jørgen (red.) 1990: Mediehåndbogen. København: Gyldendal. Mårup, Egon 2001: Sønderjysk ordbog [online]. http://www.synnejysk.dk (tilgået 17.1.2011).

Nielsen, Martin/Zethsen, Karen Korning 2004: Vondt snakke man å synnejysk, vondt skriwe man å synnejysk? I LexicoNordica 11, 299-307 [online]. http://www.ethnologue.com (tilgået 17.1.2011).

Martin Nielsen 